\title{
Trace Element ANd SR-Nd-Pb-HF Isotope EvidenCE FOR AnCIENT Fluid- RELATED ENRICHMENT In THE SOURCE REgion OF ALDAN SHIELd LAMPROITES
}

\author{
Gareth Davies $^{1}$, Joe Stolz ${ }^{2}$, Ivan Mahotkin ${ }^{3}$, Geoff Nowell ${ }^{4}$, Graham Pearson ${ }^{4}$ \\ 1 FALW, VU Amsterdam, The Netherlands, 2 MPI, Mainz, Germany, 3 IGEM, Moscow, Russia, 4 Dep. of Geological Sciences, Durham University UK
}

\section{INTRODUCTION}

\section{INTRODUCTION AND GEOLOGICAL SETTING}

The ultimate source of ultrapotassic-ultramafic rocks such as lamproites remains controversial with the relative role of sub-continental lithospheric mantle (SCLM) and sub-lithospheric sources debated (e.g., Smith, 1983, Nowell et al., 1999). In an attempt to resolve this long running debate a detailed geochemical study is presented from Mesozoic lamproitic magmatism in eastern Siberia. Lamproites are widespread, but volumetrically trivial, in the northern part of the Aldan Shield (Mahotkin et al., 1989). Lamproite magmatism appears the product of collisionrelated tectonic activity associated with the development and accretion of a series of island arc systems along the southern margin of the Aldan Shield. Evidence of the Mesozoic magmatism is preserved in a discontinuous belt $500 \mathrm{~km}$ long and $\sim 150 \mathrm{~km}$ wide. This belt is $500 \mathrm{~km}$ north of the Mesozoic collision zone. Magmatism was associated with local NE/SW extension between uplifted crustal blocks.

\section{LAMPROITE MAGMATISM}

The ultrapotassic magmatism is closely associated with other mafic and ultramafic volcanics. Magmatism appears to record a temporal evolution from subalkaline $(\sim 180$ Ma, minettes, syenites, trachytes and monzonites) to potassic $(\sim 150 \mathrm{Ma}$, leucitites, phonolites and alkaline syenites and granites) and ultimately the ultra-potassic lamproites (143-122 Ma). The lamproites occur in two suites. In the Central Aldan Block (143-136 Ma), lamproites were emplaced in the form of sills (1-3 m thick), dykes (1-20 m thick) and pipes. These lamproites are olivine, diopside, phlogopite and Cr-spinel phyric set in a cryptocrystalline matrix. The rocks are highly porphyritic with both olivine and diopside forming between 15 and $40 \%$ of the rock. The abundance of phlogopite phenocrysts is more variable (3 to 25\%). Olivine and diopside phenocrysts are highly magnesian (Mg\# 88-95). Coupled with the high Cr\# of the spinels (85-96) these mineral compositions suggest derivation of the magmas from a depleted mantle source. Lamproites in the Olekma Block (133-120 Ma) occur principally as dykes. There are two major mineralogy differences with lamproites of the Central Block. First, richteritic amphibole is a common phenocryst phase. Second, olivine and diopside phenocrysts have slightly lower abundances and lower $\mathrm{Mg \#} \mathrm{(88-90).} \mathrm{More}$ extensive petrographic descriptions can be found in Mahotkin et al. (1989), Mues et al. (1995), Panina (1997) and Vladykin (1997).

\section{MAJOR AND TRACE ELEMENT DATA}

Major elements and several trace elements $(\mathrm{Cr}, \mathrm{Ni}$, $\mathrm{Sc}, \mathrm{V})$ for the samples in this study were analysed with a Philips PW1400 X-ray fluorescence spectrometer at IGEM in Moscow. To ensure accurate determination of key trace element contents, the remaining trace element data were determined by Spark Source Mass Spectrometry at the MPI Mainz. Details of the analytical methods, precision and accuracy of the SSMS technique are given by Jochum et al. (1990). These data are complimented by ICP-MS determinations at Amsterdam. Isotope ratios were determined in Mainz $(\mathrm{Pb})$, Amsterdam (Sr-Nd) and Durham (Hf).

The lamproites all display primitive chemical characteristics with high $\mathrm{MgO}$ (up to 22.7 wt.\%), $\mathrm{Cr}$, Ni and $\mathrm{Mg}$ number. Although some of the olivine phenocrysts in the most Mg-rich samples are likely to be of cumulate origin, their high mg-values (88-94.6) indicate they crystallised from $\mathrm{Mg}$-rich primary melts. The ultrapotassic character of these melts is reflected by high $\mathrm{K}_{2} \mathrm{O}$ (up to 8.3 wt.\%), low $\mathrm{Na}_{2} \mathrm{O}$ (mostly $\leq 1.5$ wt.\%) and high $\mathrm{K}_{2} \mathrm{O} / \mathrm{Na}_{2} \mathrm{O}$ values. The Aldan lamproites have somewhat higher $\mathrm{CaO}$ with relatively low $\mathrm{Al}_{2} \mathrm{O}_{3}$ compared with many other lamproites, particularly those from Spain (Venturelli et al., 1984) and the Kimberly region of Western Australia (Jaques et al., 1986). Consequently a number of the Aldan samples fall in the overlapping fields for lamproites and kamafugites in a diagram of $\mathrm{Al}_{2} \mathrm{O}_{3}$ versus $\mathrm{CaO}$ (Foley et al., 1987). Perhaps the most distinctive feature of the major and minor element chemistry of these rocks is their low $\mathrm{TiO}_{2}$ contents $(0.5-1.4$ wt. $\%)$. In a number of examples the low $\mathrm{TiO}_{2}$ concentrations are coupled with low $\mathrm{P}_{2} \mathrm{O}_{5}(0.25-0.7$ wt.\%).

The lamproites are generally characterised by high concentrations of the compatible trace elements $\mathrm{Cr}$ and $\mathrm{Ni}$, but only moderate $\mathrm{Sc}$ and $\mathrm{V}$ concentrations compared with alkaline basaltic rocks. Incompatible element concentrations are extremely variable. Some of the incompatible K-group elements occur in high concentrations (e.g., $\mathrm{Rb}, \mathrm{Ba}$ and $\mathrm{Pb}$ up to $600 \mathrm{x}$ primitive mantle), but the high field strength elements (HFSE; Zr, Nb, Hf, Th and U) and the LREE display 
unusually low concentrations for ultra-potassic rock types. The chondrite-normalised REE patterns for the Aldan lamproites contrast markedly with those for the similar relatively Ti-poor Spanish lamproites. The latter are characterised by steep strongly LREE-enriched patterns $\left(\mathrm{La} / \mathrm{Yb}_{\mathrm{N}}>100\right)$ with a distinct negative $\mathrm{Eu}$ anomaly. The Aldan K-rich rocks do not have Eu anomalies and have significantly lower degrees of LREE enrichment $\left(\mathrm{La} / \mathrm{Yb}_{\mathrm{N}}=9.8\right.$ to 47$)$. These chemical characteristics are summarised in a primitive mantle-normalised diagram (Fig. 1), which shows marked relative enrichment in large-ion-lithophile elements (LILE; $\mathrm{Cs}, \mathrm{K}, \mathrm{Ba}, \mathrm{Rb}, \mathrm{Sr}$ and $\mathrm{Pb}$ ) coupled with strong relative depletion (or lack of enrichment) of the HFSE and LREE. The most notable features are the pronounced relative depletion of $\mathrm{Nb}$ and enrichment of $\mathrm{Pb}$ and $\mathrm{Sr}$, which contrast strongly with the signature of a typical lamproite from Western Australia. The Aldan Shield lamproites therefore have features that are widely regarded as diagnostic of subduction-related magmatism, and indeed this signature is similar to that of olivine leucitite lavas from modern island arc settings (e.g., Stolz et al., 1990). significantly lower than low- $\mathrm{TiO}_{2}$ lamproites from Spain and the Leucite Hills. Ti/Zr ratios are, however, highly variable covering the range of all known lamproites (e.g., Aldan 8 to $>200$; W. Australia $~ 25$ Leucite Hills $\sim 10)$. This heterogeneity probably reflects the significant effect of minor crystallisation of Ti-rich phases such as phlogopite on the low $\mathrm{TiO}_{2}$ contents of the Aldan lamproites. In contrast the remaining HFSE record little evidence of fractionation. $\mathrm{Zr} / \mathrm{Hf}$ and $\mathrm{Nb} / \mathrm{Ta}$ ratios are between 30 and 45 and 15 and 18 respectively despite an order of magnitude variation in elemental concentrations.

Despite relative $\mathrm{Nb}$-Ta depletion, the majority of subduction related magmatism has $\mathrm{Nb} / \mathrm{Ta}$ ratios comparable to MORB ( 17; Stolz et al., 1996). Highly depleted MORB and back-arc thoeliites have lower $\mathrm{Nb} / \mathrm{Ta}$ (Stolz et al., 1996). These data support experimental determinations that suggest that HFSE are not significantly transport by fluid and that $\mathrm{Nb} / \mathrm{Ta}$ fractionation is not recorded by large degree partial melts. Residua that have undergone multiple melting events, back-arc and highly depleted MORB, record

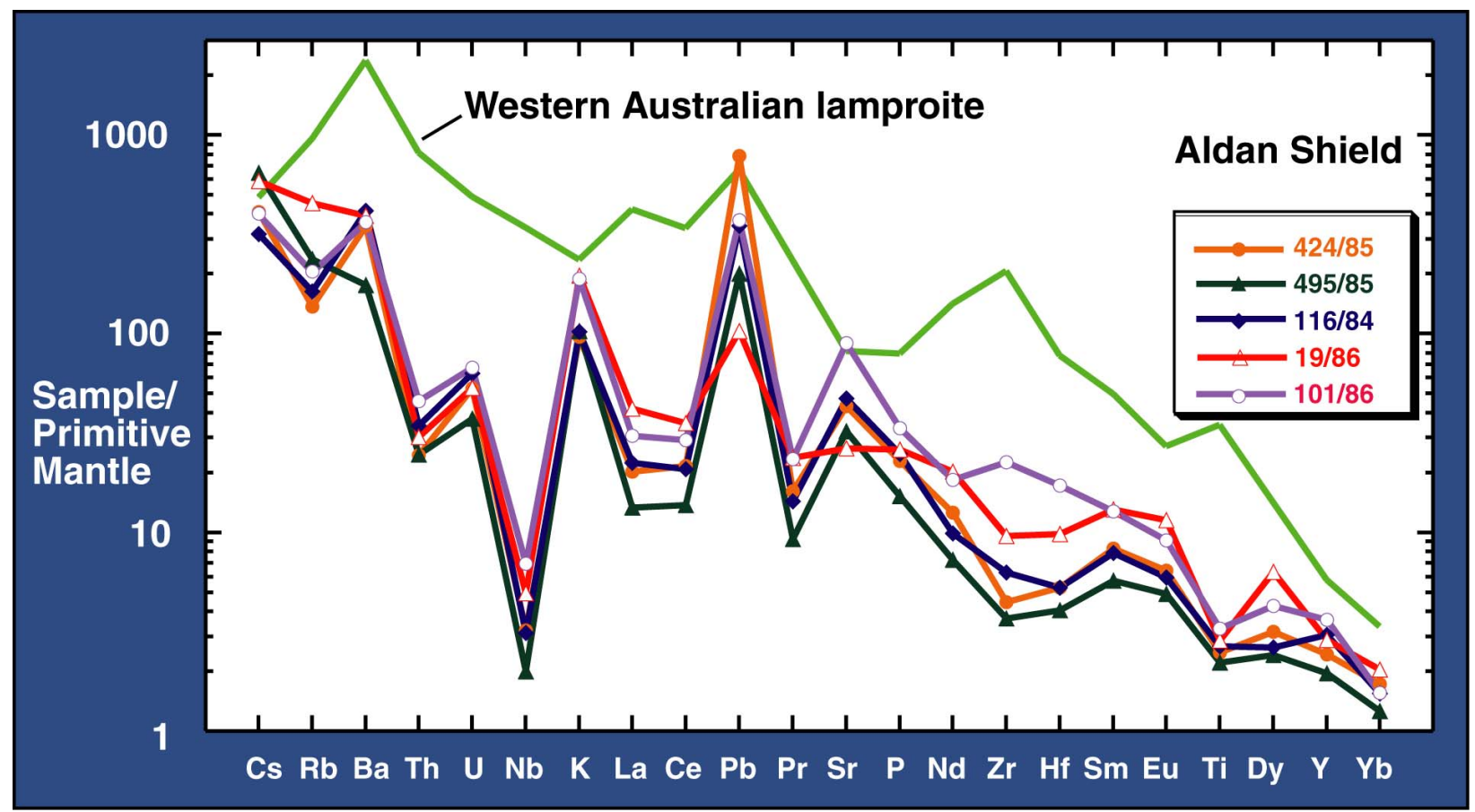

Figure 1. Primitive mantle normalised diagram

Figure 1 demonstrates that all HFSE record less relative enrichment than elements with a similar degree of incompatibility during melting. For example $\mathrm{Zr}$ and Hf have lower normalised contents than $\mathrm{Sm}$. $\mathrm{Zr}$ and $\mathrm{TiO}_{2}$ contents are lower than in any other known lamproitic magmas, with for example $\mathrm{Zr}$ contents lower $\mathrm{Nb} / \mathrm{Ta}$ (Stolz et al., 1996). In contrast, K-rich volcanics have fractionated $\mathrm{Nb} / \mathrm{Ta}$ ratios (25-35), suggesting the involvement of small degree partial melts of subducted slabs (Stolz et al., 1996). By analogy the marked relative HFSE depletion of Aldan lamproites is interpreted as a consequence of fluidrelated enrichment of incompatible trace elements and that the fluid did not transport HFSE. Furthermore, the 
low HFSE contents of the Aldan lamproites are not a consequence of HFSE depletion by some form of HFSE extraction process that would cause fractionation of HFSE. The fluid dominated enrichment process has resulted in extremely low $\mathrm{Nb} / \mathrm{U}(<10)$ and $\mathrm{Ce} / \mathrm{Pb}$ as low as 0.7 and high $\mathrm{La} / \mathrm{Nb}$ and $\mathrm{Ba} / \mathrm{Nb}$ ratios. All these trace element ratios are diagnostic of subudction, i.e., fluid, related trace element enrichment. This conclusion raises the question as to when this enrichment event occurred. If the enrichment is in the lithopshere was it associated with the formation of the Aldan Shield at 2.8-3.4 Ga, stabilisation of the Craton at $\sim 1.9 \mathrm{Ga}$ or Mesozoic collision? have much more radiogenic $\mathrm{Sr}$ and slightly more radiogenic $\mathrm{Nd}$ (Fig. 2).

Hf isotope ratios are also variable $\left(\varepsilon_{\mathrm{Hfi}}=-9.8\right.$ to 31.7). The lowest initial ratios are among the most unradiogenic values measured for mantle-derived magmatic rocks to date. Partial melting in the mantle is thought to lead to a coupled fractionation in $\mathrm{Sm} / \mathrm{Nd}$ and $\mathrm{Lu} / \mathrm{Hf}$ ratios such that present day oceanic and subduction related volcanism and continental crust form a well defined liner relationship between $\mathrm{Nd}$ and $\mathrm{Hf}$ isotopes. The majority of the Aldan lamproites lie on an extension of the oceanic array at less radiogenic values

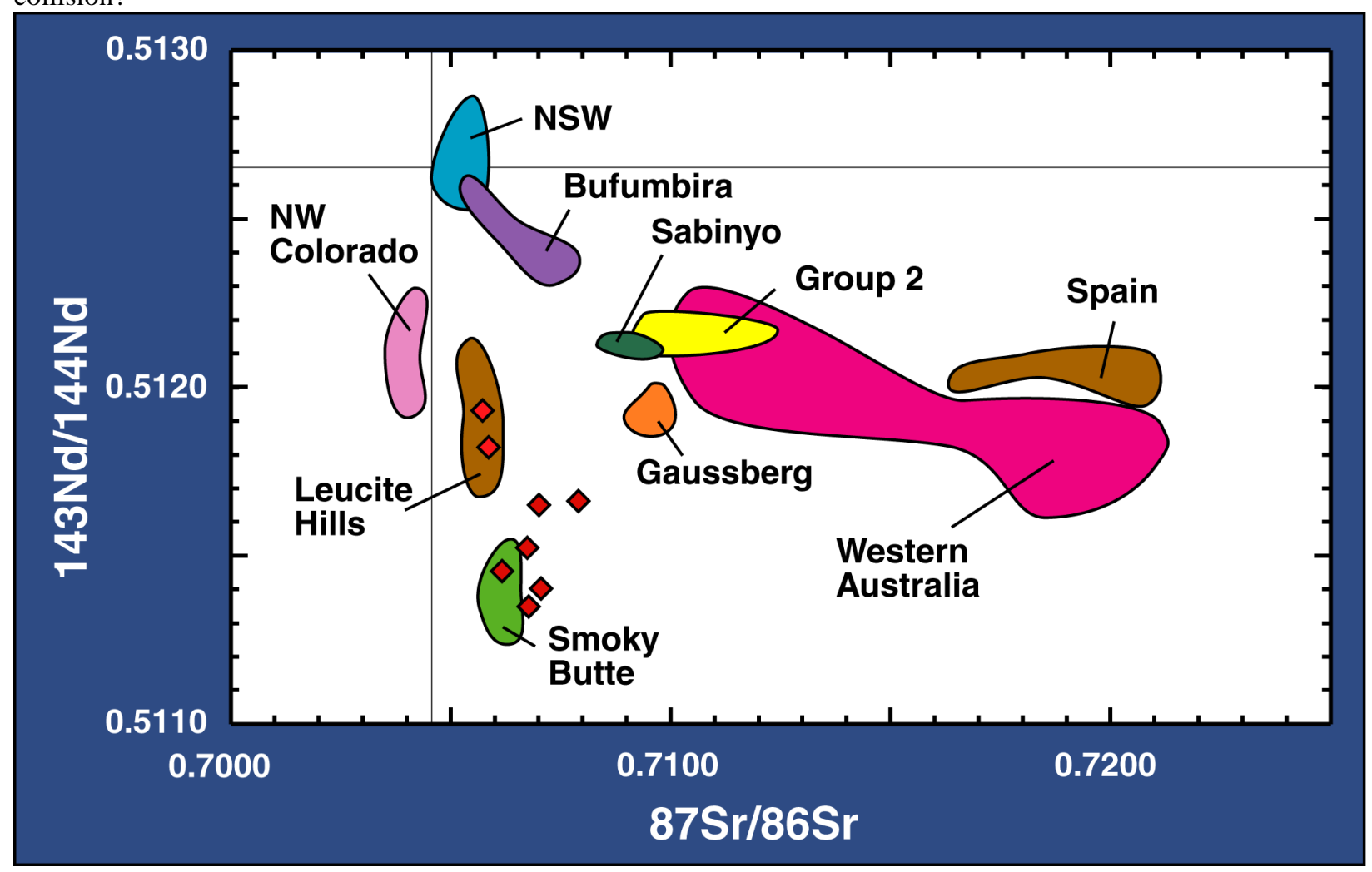

Figure 2: Nd-Sr isotope diagram

\section{$\mathrm{Rb}-\mathrm{Sr}, \mathrm{Sm}-\mathrm{Nd}$, U-Pb and Lu-Hf isotope systematics}

Aldan lamproites are characterised by very unradiogenic $\mathrm{Nd}\left(\varepsilon_{\mathrm{Ndi}}=-8.6\right.$ to -22.2$)$ and, when compared to Bulk Earth, moderately radiogenic $\mathrm{Sr}$ $\left({ }^{87} \mathrm{Sr}^{86} \mathrm{Sr}_{\mathrm{i}}=0.7056\right.$ to 0.7079$)$. Several samples from the Central Aldan Block fall within the field for lamproites from the Leucite Hills at moderately negative $\varepsilon_{\mathrm{Ndi}}$ values, and the remainder plot within or close to the field for the Smoky Butte lamproites (Fraser et al., 1985). These suites contrast with the Spanish and Western Australian K-rich rocks which than Group II kimberlites (Nowell et al. 1999).

Departure from the oceanic array is expressed in $\Delta \varepsilon_{\mathrm{Hf}}$ notation. The lamproites with the most extreme isotopic ratios plot both above and below the oceanic array, $\Delta \varepsilon_{\mathrm{Hf}}+2$ to -7 . Unpublished Nd-Hf isotope data from other lamproites have similar characteristics (Nowell et al., 1998) demonstrating that all lamproitic sources are derived from a mantle source characterised by very long-term LREE enrichment. The $\mathrm{Nd}-\mathrm{Sr}$ relationships establish that this source has variable $\mathrm{Rb} / \mathrm{Sr}$, with the source of Siberian and N. American lamproites recording moderate time-integrated $\mathrm{Rb} / \mathrm{Sr}$ enrichment while Spanish and W. Australian lamproites have higher $\mathrm{Rb} / \mathrm{Sr}$. Despite the effects of parentdaughter ratio fractionation during the Mesozoic partial 
melting event that produced the lamproites, the lamproites have depleted mantle model ages for $\mathrm{Nd}$ and Hf that are consistently ancient, 1.5 to $3.0 \mathrm{Ga}$.

The $\mathrm{Pb}$ isotope data for the Aldan rocks are also very distinctive and among the least radiogenic values published for lamproites. $\mathrm{Pb}$ isotope ratios of the Aldan rocks fall in two discrete fields that, on a diagram of ${ }^{206} \mathrm{~Pb} /{ }^{204} \mathrm{~Pb}$ vs. ${ }^{207} \mathrm{~Pb} /{ }^{204} \mathrm{~Pb}$, overlap with the Leucite Hills and Smoky Butte lamproites (Fraser et al., 1985). These rocks all have relatively unradiogenic $\mathrm{Pb}$ and plot, close to or, to the left of the Geochron. This is in contrast to the majority of MORB, OIB and other Krich rocks from New South Wales, Africa and Spain. The data plot both above and below the Northern Hemisphere Reference line defined by the majority of Atlantic oceanic magmatism. The relationships are similar in the ${ }^{206} \mathrm{~Pb} /{ }^{204} \mathrm{~Pb}$ vs. ${ }^{208} \mathrm{~Pb} /{ }^{204} \mathrm{~Pb}$ diagram with the Aldan rocks overlapping in part with the Leucite Hills rocks. However, the group of Aldan rocks with the lowest ${ }^{206} \mathrm{~Pb} /{ }^{204} \mathrm{~Pb}$ values has higher ${ }^{208} \mathrm{~Pb} /{ }^{204} \mathrm{~Pb}$ values than the Smoky Butte rocks and is more radiogenic than the NHRL. This suggests that the mantle source had higher time-integrated $\mathrm{Th} / \mathrm{Pb}$ and $\mathrm{Th} / \mathrm{U}$ values than the Smoky Butte source.

The $\mathrm{Pb}$ isotope data define a mixing array that has a slope equivalent to an age of $\sim 3.0 \mathrm{Ga}$. If interpreted in terms of a multi-stage $\mathrm{Pb}$ evolution, the data require fractionation from a Bulk Earth reservoir $(\mu=8.99)$ at $3.0 \mathrm{Ga}$ and subsequent evolution with second stage $\mu$ values between 6.30 and 7.99. Irrespective of if the slope of the data has actual age significance or not, the data clearly establish long term evolution of the source with high time-integrated $\mathrm{Th} / \mathrm{Pb}$ and $\mathrm{Th} / \mathrm{U}$ and low $\mathrm{U} / \mathrm{Pb}$.

\section{DISCUSSION AND CONCLUSIONS}

The Aldan Shield lamproites record a style of trace element enrichment unique among lamproites. The extreme enrichment in LILE and $\mathrm{Pb}$, moderate enrichment in LREE and approximately primitive mantle abundances of HFSE implies source enrichment dominated by hydrous fluids. The lack of fractionation among HFSE is characteristic of the absence of a silicate melt during the trace element enrichment. The $\mathrm{Nd}-\mathrm{Hf}-\mathrm{Pb}$ isotope data provide consistent evidence of an early Archaean fractionation event in the source of the Aldan lamproites.

Distinguishing between potential sources of the lamproites, SCLM or sublithospheric, in the form of a plume source, relies partly on circumstantial evidence. The ancient $\mathrm{Nd}-\mathrm{Hf}$ and $\mathrm{Pb}$ model ages are comparable to a major collisional phase within the Siberian Craton at 2.8 Ga (Rosen et al., 2002), which implies a SCLM source. Ancient recycling and storage at the coremantle boundary could, however, preserve an ancient isotopic signature.

The variable $\mathrm{Sr}-\mathrm{Nd}-\mathrm{Pb}$ isotope composition of the SCLM has been widely documented. The Hf-Nd isotope relationships of depleted SCLM (e.g., Simon et al., this issue) record long term but variable LREE enrichment (low to high Nd isotopes) and high Lu-Hf (high Hf isotopes). The depleted SCLM is therefore characterised by highly positive $\Delta \varepsilon_{\mathrm{Hf}}$. The negative $\varepsilon_{\mathrm{Hf}}$ and particularly negative $\Delta \varepsilon_{\mathrm{Hf}}$ of the Aldan lamproites requires a source with long term low $\mathrm{Lu} / \mathrm{Hf}$ and $\mathrm{Sm} / \mathrm{Nd}$ with fractionation (lowering) of $\mathrm{Lu} / \mathrm{Hf}$ being greater than for $\mathrm{Sm} / \mathrm{Nd}$. This source is clearly not the depleted SCLM. Depleted sources, however, are unlikely to produce ultra-potassic ultra-basic magmas.

The key to deciphering the lamproite source is their "subduction-related" trace element signature. A water dominated petrogenesis requires formation above a dehydrating slab. Transport and long-term storage and preservation of this signature at depth in the mantle is unlikely. Trace element signature would be destroyed/ homogenised because water-rich material would tend to melt and, at great depth, rapid diffusion would homogenise any small scale "subduction" signal with the convecting mantle. The lamproites are therefore considered to be derived from an easily melted, highly metasomatised source within the SCLM. This source has high $\mathrm{Rb} / \mathrm{Sr}$ and low $\mathrm{U} / \mathrm{Pb}, \mathrm{Lu} / \mathrm{Hf}, \mathrm{Sm} / \mathrm{Nd}$ and low $\mathrm{Lu} / \mathrm{Hf} / \mathrm{Sm} / \mathrm{Nd}$. These characteristics are perfectly in agreement with fluid enrichment involving minor movement of LILE, LREE+Hf but not HREE+Lu. Highly metasomatised peridotites (e.g., MARID, PKP) and enriched pyroxenites (e.g., Nowell et al., in press) have the combined $\mathrm{Sm} / \mathrm{Nd}-\mathrm{Lu} / \mathrm{Hf}$ parent daughter ratios to produce the negative $\varepsilon_{\mathrm{Hf}}$ and negative $\Delta \varepsilon_{\mathrm{Hf}}$ of the Aldan Shield lamproites.

\section{REFERENCES}

Foley, S.F., Venturelli, G., Green, D.H., Toscani, L.,1987 The ultrapotassic rocks; characteristics, classification, and contraints for petrogenetic models. Earth-Science Reviews, 24: 81-134.

Fraser, K.J., Hawkesworth, C.J., Erlank, A.J., Mitchell, R.H., Scott Smith, B.H. 1985. Sr, Nd and Pb isotope and minor element geochemistry of lamproites and kimberlites. Earth and Planetary Science Letters, 76, 57-70.

Jacques, A.L., Lewis, J.D., Smith, C.B., 1986. Kimberlites and lamporites of Western Australia. 
Geological Survey Western Australia. Bulletin 132, 268.

Jochum, K.P., Seufert, H.M., Thirlwall, M.F., 1990. High-sensitivity $\mathrm{Nb}$ analysis by spark-source mass specrtometry (SSMS) and calibration of XRF $\mathrm{Nb}$ and Zr. Chem. Geol. 81, 1-16.

Mues-Schumacher, U., Keller. J., Konova, V., Suddaby, P., 1995. Petrology and age determinations of the ultramafic (lamporitic) rocks from the Yakokut complex, Aldan Shield, Eastern Siberia. Mineralogical Magasine 59, 409-428.

Panina, L.I., 1997. Low-Titanium Aldan lamporites (Siberia): melt inclusions in minerals. 1997. Russian Geology and Geophysics: 38, No.1 118-127.

Mahotkin, I.L. Arakelyatz, M.M. Vladykin, N.V., 1989 Age of the Aldan lamporites province. Dokl. Akad. Nauk SSSR, 306: 703-707.

Nowell, G.M. Pearson, D.G., Kempton, P.D., Irving, A.J., Turner, S., 1998. A Hf isotope study of Lamproites: Implications for their origins and relationship to Kimberlites. Ext. Abs. $7^{\text {th }}$ Int. Kimb. Conf. Cape Town. 637-639.

Nowell, G.M. Pearson, D.G., Kempton, P.D., Noble, S.R., Smith, C.B., 1999. Origins of Kimberlites: A Hf isotope perspective. Proc. $7^{\text {th }}$ Int. Kimb. Conf. Cape Town. 616-623.

Nowell, G., Pearson, D., Bell, D., Carlson, R., Smith, C., Kempton, P.D., Noble, S., 2003. Hf isotope systematics of kimberlites and their megacrysts: new constraints on their source regions. Journal of Petrology, in press.

Panina, L.I., 1997. Low-Titanium Aldan lamporites (Siberia): melt inclusions in minerals. 1997. Russian Geology and Geophysics: 38, No.1 118-127.

Rosen, O.M., Serenko, V.P., Spetsius, Z.V., Manakov, A.V., Zinchuk, N.N. 2002. Yakutian kimberlite province: position in the structure of the Siberian Craton and composition of the upper and lower crust. Rus. Geol. Geophys. 43, 1-24.

Simon, N.S.C., Carlson, R.W., Davies, G.R., Pearson, D.G., 2003. Os-Sr-Nd-Hf Isotope Evidence for the Ancient Depletion and Subsequent Multi-Stage Enrichment History of the Kaapvaal Craton. This issue.

Smith, C.B.,1983. Pb,Sr and $\mathrm{Nd}$ isotopic evidence for sources of Southern African cretaceous Kimbetlites. Nature: 304, 51-54.

Stolz, A.J., Jochum, K.P., Spettel, B., Hofmann, A.W., 1996. Fluid- and melt-related enricmnet in the subarc mantle: Evidence from $\mathrm{Nb} / \mathrm{Ta}$ variations in island-arc basalts. Geology 24, 587-590.

Stolz, A.J., Varne,R., Davies,G.R., Wheller, G.E., Foden, J.D., 1990 magma source components in an arc-continent collision zone: the Flores-Lembata sector, Sunda arc, Indonesia. Contribution Mineralogy Petrology 105: 585-601.

Vladykin, N.V., 1997. Geochemistry and genesis of lamporites of the Aldan Shield. 1997. Russian Geology and Geophysics: Vol 38, no.1 128-141.

Contact: Gareth Davies, FALW, Vrije Universiteit Amsterdam, De Boelelaan 1085, 1081 HV Amsterdam, The Netherlands, E-mail: gareth.davies@falw.vu.nl 